\title{
Weed Interference Periods in the 'Fécula Branca' Cassava'
}

\author{
Periodos de Interferência das Plantas Daninhas na Variedade de Mandioca Fécula Branca
}

\author{
COSTA, N.V.. ${ }^{2}$ RITTER, L. ${ }^{3}$, PERES, E.J.L. ${ }^{3}$, SILVA, P.V. ${ }^{3}$, and VASCONCELOS, E.S. ${ }^{2}$
}

ABSTRACT - This study aimed to determine the periods of weed interference in the first cycle of 'Fécula Branca' cassava. The experiment was arranged in a randomized block design, with four repetitions. The treatments consisted of eight periods of weed control $(25,50,75,100$, 125,150 , and 175 days after planting - DAP) and eight periods of coexistence between the weed community and the crop $(25,50,75,100,125,150$, and 175), besides control without weeds and control with weeds until harvest (322 DAP). The predominant weed species with higher relative importance were: Avena sativa, Sorghum halepense, Conyza Canadensis, Euphorbia heterophylla, Raphanus raphanistrum, and Commelina benghalensis. It was concluded that, accepting losses of $1 \%$ for root and starch production, the period before interference (PBI) was 66 and 70 DAP; the total period of interference prevention (TPIP) was 88 and 91 DAP and the critical period of interference (CPI) was between 66-88 and 70-91 DAP, respectively. For losses of 5\% for root and starch production, the PBI was 87 and 88 DAP, and the TPIP 80 and 81 DAP, respectively; in this case, there was no CPI. Considering the average prices of $\mathrm{R} \$ 218.90 \mathrm{t}^{-1}$ and $\mathrm{R} \$ 1,191.84 \mathrm{t}^{-1}$, paid in 2012 for root and starch production, respectively, and control cost of $\mathrm{R} \$ 300.00 \mathrm{ha}^{-1}$, the root and starch production for the period prior to economic loss (WEEPPEL) could be estimated to be 20 and 24 DAP, respectively.

Keywords: cassava, Manihot esculenta, weed interference, WEEPPEL.

\begin{abstract}
RESUMO - Objetivou-se neste trabalho determinar os periodos de interferências das plantas daninhas no primeiro ciclo da cultura da mandioca Fécula Branca. O delineamento utilizado foi o de blocos casualizados com quatro repetições. Os tratamentos constituíram-se de sete periodos de controle das plantas daninhas (25, 50, 75, 100, 125, 150 e 175 dias após o plantio-DAP) e de sete periodos de convivência entre a comunidade de plantas daninhas e a cultura (25, 50, 75, 100, 125, 150 e 175 DAP), além de testemunha capinada e outra testemunha sem capina, até a colheita (322 DAP). As espécies de plantas daninhas que predominaram e apresentaram maiores indices de importância relativa foram: Avena sativa, Sorghum halepense, Conyza canadensis, Euphorbia heterophylla, Raphanus raphanistrum e Commelina benghalensis. Concluiu-se que, aceitando-se perdas de 1\% para produção de raizes e fécula, o PAI foi de 66 e 70 DAP; o PTPI, 88 e 91 DAP; e o PCPI, entre 66 e 88 e 70 a 91 DAP, respectivamente. Para perdas de 5\% na produção de raizes e fécula, o PAI foi de 87 e 88 DAP e o PTPI, de 80 e 81 DAP, respectivamente; para este caso, não houve o PCPI. Considerando-se valores médios pagos em 2012 para raizes e fécula de $R \$ 218,90 t^{-1}$ e $R \$ 1.191,84 t^{1}$, respectivamente, e o custo de controle de $R \$ 300,00$ ha $^{-1}$ foi possivel estimar para os rendimentos de raizes e fécula o periodo anterior ao dano no rendimento econômico (PADRE) de 20 e 24 DAP, respectivamente.
\end{abstract}

Palavras-chave: mandioca, Manihot esculenta, matointerferência, PADRE.

Recebido para publicação em 23.7.2012 e aprovado em 8.12.2012.

${ }^{2}$ Adjunct professor, Universidade Estadual do Oeste do Paraná - UNIOESTE/CCA, Marechal Cândido Rondon-PR, $<$ neumarcio.costa@unioeste.br>; ${ }^{3}$ Agronomy Students, UNIOESTE/CCA, Marechal Cândido Rondon-PR. 


\section{INTRODUCTION}

Cassava (Manihot esculenta) presents a perennial cycle and has many advantages, such as the possibility of obtaining high productivity, high tolerance to drought and degraded soils or acids and easy adaptation to environments where the planting of other crops would be more risky, playing an important role in human and animal foods and in the industrial processing of flour and starch (Johanns \& Contiero, 2006).

The western region of Paraná stood out in the 2011/2012 season among the major producers of cassava, with a crop yield of $28.3 \mathrm{t} \mathrm{ha}^{-1}$, higher than the state average of $22.6 \mathrm{t} \mathrm{ha}^{-1}$ and the national average of 14.7 t ha $^{-1}$ (IBGE, 2011; IPARDES, 2011; Paraná, 2012). It is noteworthy that most of the cassava grown in western Paraná is intended for industrial starch and flour, where the use of the 'Fécula Branca' variety stands out.

However, cassava producers in this region reveal that the interference caused by the weeds significantly reduces the crop yield potential, in addition to the extremely difficult control due to the high cost of weeding and lack of options for selective herbicides registered for culture.

Johanns \& Contiero (2006), in a study conducted in Marechal Cândido Rondon, PR, found a PBI of 60 days and a TPIP of 90 days for the 'Fécula Branca' variety, indicating a CPI of 60-90 days after planting (DAP). Albuquerque et al. (2008), in Viçosa-MG, determined that the critical period for the Cacauzinha variety was between 25 and 75 DAP.

Some studies performed obtained losses near 90\% (Peressin et al. 1998; Albuquerque et al., 2008).

Variations between the results shown can be attributed to soil and climate differences, infestation and composition of weeds in the area, cultivar, spacing and many other factors specific to each site.

It can be noted that weed control stands out as a key component of agricultural production (Zoschke \& Quadranti, 2002). Thus, the study of interference periods of these weeds in the cassava crop becomes important in the development of an integrated system with different strategies for managing these species in areas of sustainable production.

Studies on weed interference in crops aim to determine the critical periods of interaction between cultures and weed communities. These periods were defined by Pitelli \& Durigan (1984) as period before interference (BPI), total period of interference prevention (TPIP) and critical period of interference (CPI). However, Vidal et al. (2005) claim that economic aspects such as cost control and the monetary value of the crop must be used as a criterion to determine the acceptable weed interference period before settling on how to control them, establishing the weed period prior to economic loss (WEEPPEL) value. However, there is little information in the literature about CPI and WEEPPEL of weeds in cassava crops in agricultural areas of the western region of Paraná.

Thus, this study aimed to determine the periods of weed interference in the first cycle of the 'Fécula Branca' cassava variety in western Paraná.

\section{MATERIAL AND METHODS}

The experiment was conducted in the experimental area with the following coordinates: latitude $24^{\circ} 42^{\prime} 30^{\prime \prime} \mathrm{S}$, longitude $54^{\circ} 21^{\prime} 10^{\prime \prime} \mathrm{W}$ Grw and altitude $485 \mathrm{~m}$.

The soil of the experimental area was classified as Eutroferric Red Latosol (LVe), clayey (Embrapa, 2006), with the following characteristics: $\mathrm{pH}\left(\mathrm{CaCl}_{2}\right)=5.75$; organic matter $\left(\mathrm{g} \mathrm{dm}^{-3}\right)=19.86 ; \mathrm{P}\left(\mathrm{mg} \mathrm{dm}^{-3}\right)=9.85$; $\mathrm{H}+\mathrm{Al}, \mathrm{K}, \mathrm{Ca}, \mathrm{Mg}, \mathrm{SB}$ and CTC $\left(\mathrm{cmol}_{\mathrm{c}} \mathrm{dm}^{-3}\right)=3.31$; $0.81 ; 7.96 ; 3.74 ; 12.51$; and 15.82 ; respectively; and $\mathrm{V} \%=79.08$.

The soil was prepared with one plowing and two harrowings, sowing being held on 10/1/ 2010 , using the 'Fécula Branca' variety spaced at $0.8 \times 0.8 \mathrm{~m}$; no chemical fertilization was performed in the base.

Sowing was performed in furrows and cuttings were arranged horizontally. The planting material used was obtained from 10 to 12 month old mature plants, healthy and from the middle third of the plants, uniform in diameter. The cuttings were 
12 to $15 \mathrm{~cm}$ long, 2 to $3 \mathrm{~cm}$ wide and had 5 to 7 buds.

The experimental design was a randomized block design with four replications. Each experimental unit consisted of $6 \mathrm{~m}$ long lines, in a total area of $28.8 \mathrm{~m}^{2}(4.8 \mathrm{~m}$ wide $\mathrm{x}$ $6.0 \mathrm{~m}$ long). Prior to planting cassava, the experimental area was rotated with oilseed radish (Raphanus sativus), using a density of $20 \mathrm{~kg} \mathrm{ha}^{-1}$. The desiccation of the area was made using glyphosate at $900 \mathrm{~g} \mathrm{ha}^{-1}$.

The culture was driven by a growing cycle of 322 days, with the planting held on October $1^{\text {st }}, 2010$ and the harvest held on August $17^{\text {th }}$, 2011.

The treatments consisted of seven increasing periods of weed control $(25,50,75$, $100,125,150$ and 175 days after planting DAP) and seven periods of coexistence between the weed community and the crop $(25,50,75$, $100,125,150$ and 175 DAP), in addition to two witnesses, maintained under infestation or weed control throughout the entire growing period (322 DAP).

The weed control at the end of each period of coexistence and for the control periods was performed by hand weeding.

The characterization and phytosociological study of the weed community at the end of each period of coexistence and during the control periods was made through the inventory square method, using frames of $0.25 \mathrm{~m}^{2}(0.5 \times 0.5 \mathrm{~m})$, thrown at random on each plot. In each frame sampled, the weeds were counted and identified according to family, species and common name.

From the count of species present, the following phytosociological variables were calculated: density (D) and relative importance index (RI), calculated according to the formula proposed by Mueller-Dombois \& Ellenberg (1974).

During the harvest of the cassava for determining root $\left(\mathrm{t} \mathrm{ha}^{-1}\right)$ and starch $\left(\mathrm{t} \mathrm{ha}^{-1}\right)$ yield, six plants were collected in the two central lines of the parcels; after being cleaned, they were weighed on a $0.1 \mathrm{~g}$ precision scale.

Starch content was determined by the hydrostatic scale method of Grossman \& Freitas (1950), cited by Oliveira et al. (2011).
To determine Period Before Interference (PBI), Total Period of Interference Prevention (TPIP) and Critical Period of Interference, the method and conceptualization used were according to Pitelli \& Durigan (1984), and the equation used was proposed by Kozlowski et al. (2002). The determination of Weed Period Prior to Economic Loss (WEEPPEL) was based on the proposal suggested by Vidal et al. (2005), according to the equation: WEEPPEL $=\mathrm{CC} /$ $\left(R^{*} \mathrm{P} * \mathrm{PR}\right)$.

To calculate WEEPPEL, we considered the price range of cassava roots and starch $(\mathrm{P})$ of $\mathrm{R} \$ 70.00$ at $280.00 \mathrm{t}^{-1}$ and $\mathrm{R} \$ 400.00$ at $1600.00 \mathrm{t}^{-1}$, respectively (amounts paid in the far west of Paraná in the period from 2005 to 2012, according to data from CEPEA, 2012), and the costs of weed control (CC) of $R \$ 150.00$ to $550.00 \mathrm{ha}^{-1}$ were determined based on management adopted by the western Paraná cassava producers in crops of one and two cycles (Technical Association of Cassava Industries of Paraná - Atimop, personal communication). For yields (R) of cassava roots and starch, we adopted the values obtained in clean plots of 10 and $1.5 \mathrm{t} \mathrm{ha}^{-1}$, respectively. The income losses (PR) of roots and starch per day of coexistence of the crop with weeds were obtained by adjustments to linear regression models of segments on straight lines of cassava starch and root yield data as a function of coexistence periods of the crop with weeds; parameter $b$ (slope coefficient) of this equation, divided by parameter $a$ (intercept on the $y$ axis), results in the PR coefficient.

The data obtained for WEEPPEL were applied to surface charts constructed from multiple regression models. For further comparisons, the dollar in the experimental period cost: US\$ $1.00=\mathrm{R} \$ 1.98$.

\section{RESULTS AND DISCUSSION}

The weed community present in the experimental area consisted of 11 families and 18 species, with the class Magnoliopsida standing out with most of the species in the area. The Asteraceae and Poaceae families showed the greatest number of species, with five and three in each, respectively (Table 1).

The early emergence of weeds occurred six days after planting (DAP). We found that at 
Table 1 - List of weeds present in the experimental area by family, species and common name. 2011/2012, Paraná, BR

\begin{tabular}{|c|c|c|}
\hline Family & Species & Common name \\
\hline & Magnoliopsida & \\
\hline Amaranthaceae & Amaranthus lividus $\mathrm{L}$. & Wild Amaranth \\
\hline \multirow{5}{*}{ Asteraceae } & Bidens pilosa $\mathrm{L}$. & Cobbler's Pegs \\
\hline & Conyza canadensis (L.) Cronquist & Horseweed \\
\hline & Emilia sonchifolia L. DC. & Lilac Tasselflower \\
\hline & Galinsoga parviflora Cav. & Gallant Soldier \\
\hline & Sonchus oleraceus L. & Sow Thistle \\
\hline \multirow{2}{*}{ Brassicaceae } & Coronopus didymus (L.) Sm & Lesser Swine-Cress \\
\hline & Raphanus raphanistrum $\mathrm{L}$. & Wild Radish \\
\hline Euphorbiaceae & Euphorbia heterophylla & Wild Poinsettia \\
\hline Lamiaceae & Leonurus sibiricus L. & Honeyweed \\
\hline Malvaceae & Sida sp. & Sida \\
\hline Oxalidaceae & Oxalis latifolia $\mathrm{L}$. & Sorrel \\
\hline \multirow[t]{2}{*}{ Phyllanthaceae } & Phyllantus niruri Roxb. & Stonebreaker \\
\hline & Liliopsida & \\
\hline Commelinaceae & Commelina benghalensis $\mathrm{L}$. & Benghal Dayflower \\
\hline Convolvulaceae & Ipomoea purpurea $\mathrm{L}$ & Common Morning Glory \\
\hline \multirow{3}{*}{ Poaceae } & Avena sativa & Oat \\
\hline & Brachiaria plantaginea (Link) Hitchc. & Alexandergrass \\
\hline & Sorghum halepense (L.) Pers. & Johnsongrass \\
\hline
\end{tabular}

25 DAP the weed community was largely established in the experimental area, with densities of 43 and 65 plants $\mathrm{m}^{-2}$ for periods of control and coexistence, respectively (Figure 1).

The weed community reached the highest densities at 150 DAP (50 plants $\left.\mathrm{m}^{-2}\right)$ and at 75 DAP (114 plants $\mathrm{m}^{-2}$ ), for the periods of control and coexistence, respectively. There was no variation in the density of weeds in the control periods. However, for coexistence periods from 75 DAP there was a decrease in weed density until the end of the crop cycle.

Figure 2 shows the relative importance index (RI) of weeds in each treatment for the periods of control and coexistence.

It was found that, in the control periods, the Liliopsida class species showed the greatest IRs, especially Avena sativa and Sorghum halepense. Among the species of the Magnoliopsida class, Conyza canadensis stood out.

Planta Daninha, Viçosa-MG, v. 31, n. 3, p. 533-542, 2013
The species $C$. canadensis was present in almost all periods with high IR values, which can be explained by the fact that it is difficult to control and exhibits are resistant to the herbicide glyphosate, but $A$. sativa showed a higher IR value, reaching $77.6 \%$ at 150 DAP in control periods.

In periods of coexistence of the crop with weeds, the species of greatest importance were Euphorbia heterophylla, Raphanus raphanistrum and Commelina benghalensis.

The species $E$. heterophylla was present in all periods of coexistence, always presenting RI values above $20 \%$, reaching $38 \%$ at 75 DAP. This fact can be attributed to the cycle of the species and the seed bank on the site. The cycle of $E$. heterophylla can be considered short, allowing for two to three generations in a year, showing good growth in nearly all soil types, preferring, however, fertile and welldrained soils, with seed production in large quantities and at low dormancy (Kissmann \& Groth, 1992). 


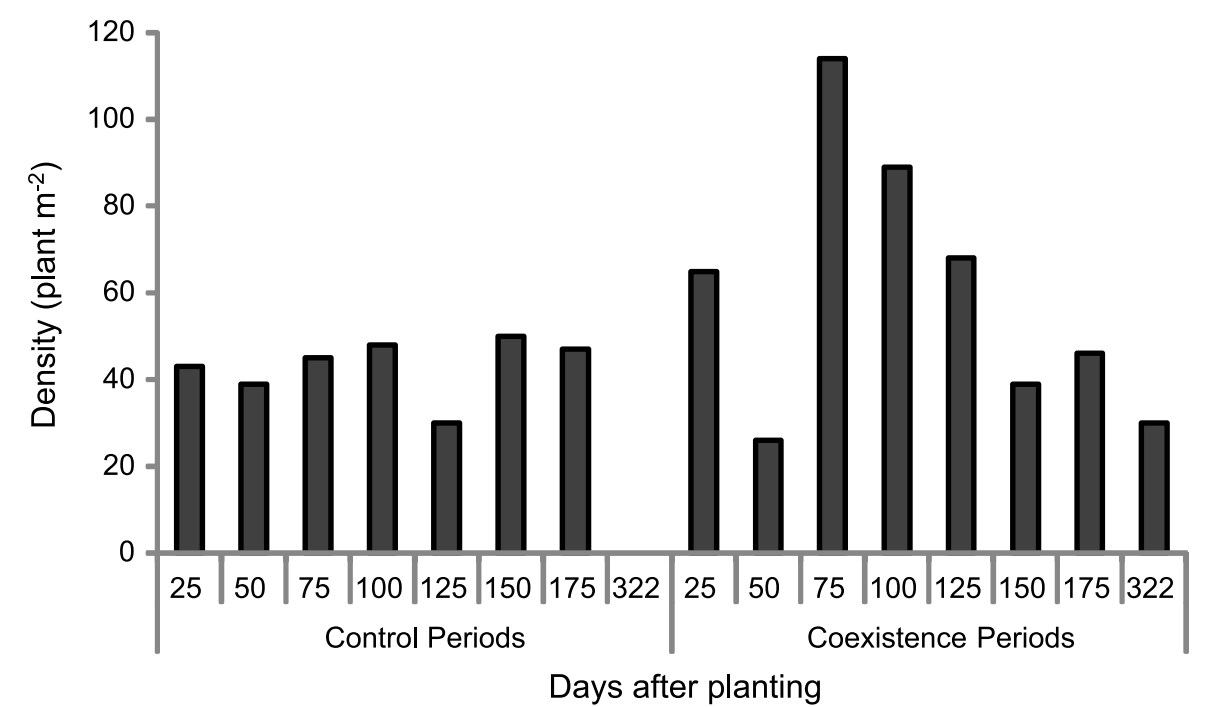

Figure 1 - Average density of weeds in each treatment for periods of control and coexistence in the 'Fécula Branca' cassava crop. 2011/2012, Paraná, BR.
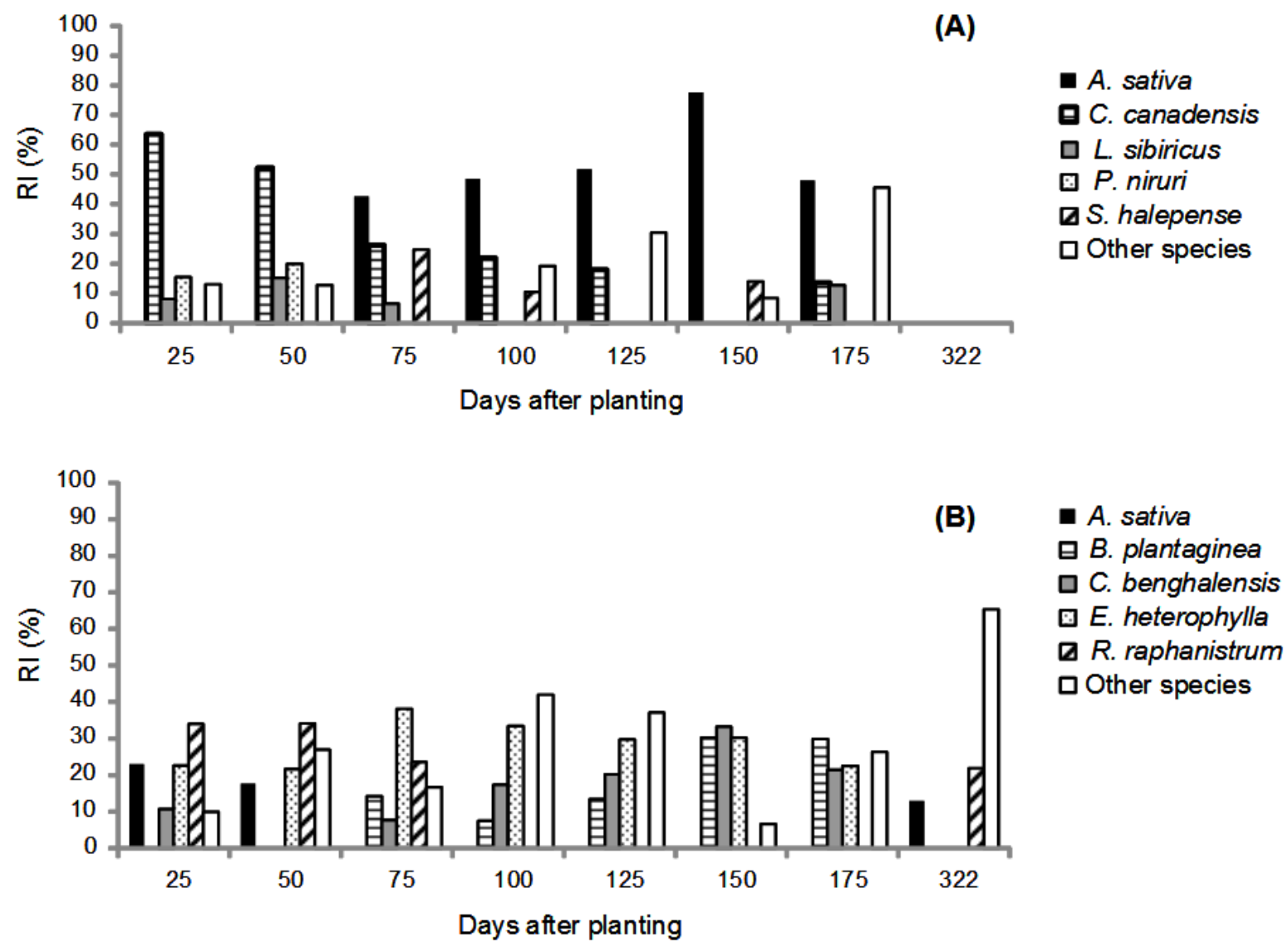

Figure 2 - Relative importance (RI) index of weeds in each treatment for the control (A) and coexistence (B) periods in in the 'Fécula Branca' cassava crop. 2011/2012, Paraná, BR. 
The weed interference caused a decrease in root production and, consequently in production of starch, which can be seen in Figures 3 and 4.
The maximum yield was reached in the treatment that was free of weeds, both in root production (Figure 3 ) and in starch production (Figure 4). Since the losses were 88.9 and

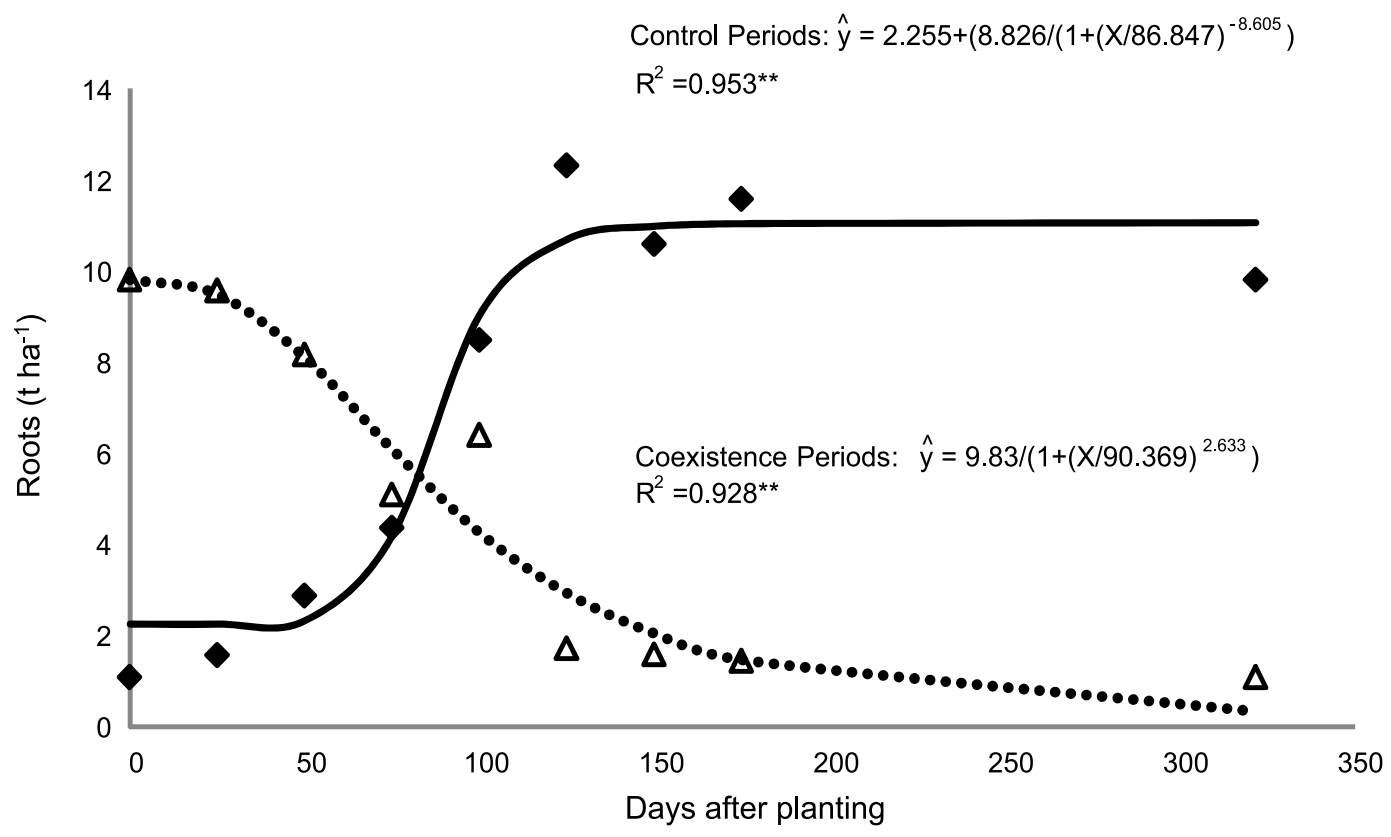

- Control Periods

$\Delta$ Coexistence Periods

Figura 3 - Production of roots ( $\left.\mathrm{t} \mathrm{ha}^{-1}\right)$ of 'Fécula Branca' cassava depending on the control and coexistence with weeds periods. ** Significant at $1 \%$ by the F-test 2011/2012, Paraná, BR.

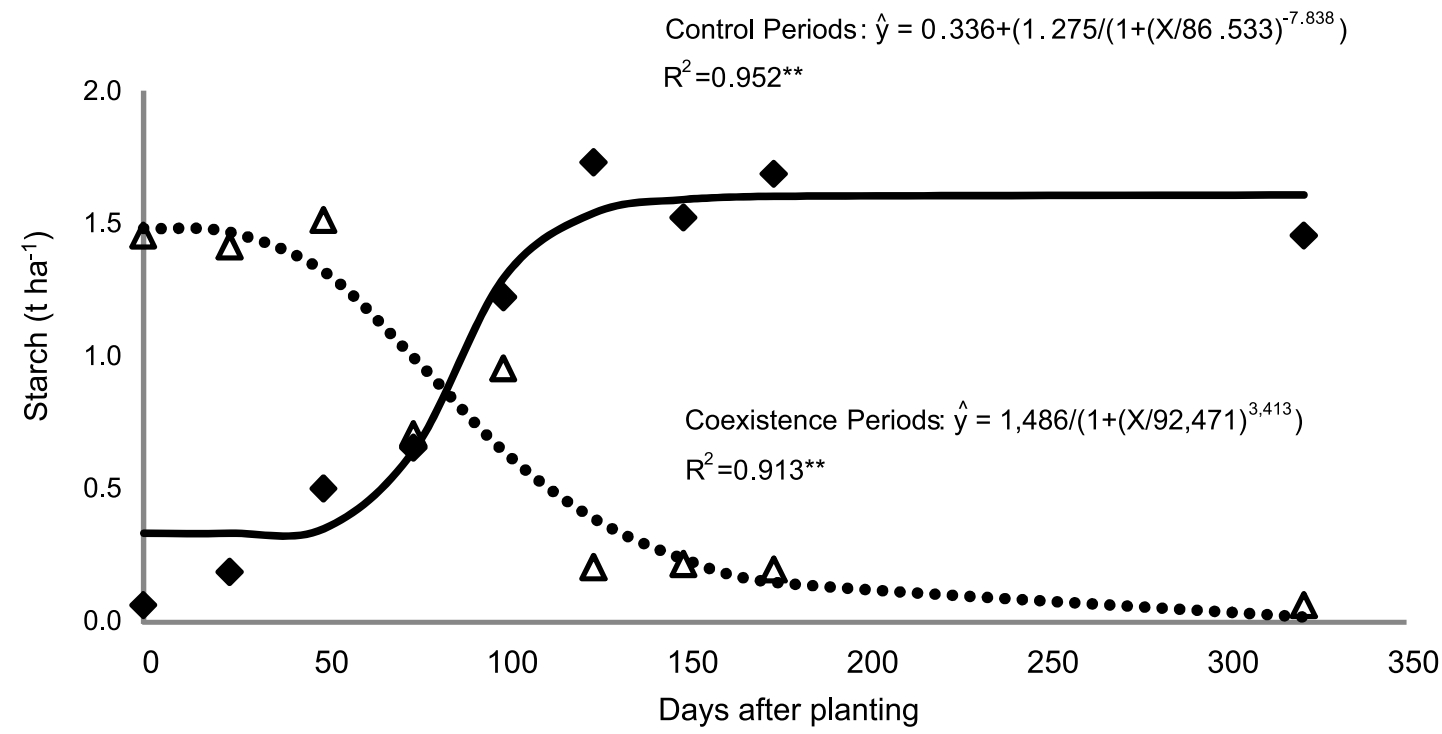

Control Periods

$\Delta$ Coexistence Periods

Figure 4 - Production of starch $\left(\mathrm{t} \mathrm{ha}^{-1}\right)$ of the 'Fécula Branca' cassava depending on the control and coexistence with weeds periods ** Significant at $1 \%$ by the F-test 2011/2012, Paraná, BR. 
$95.6 \%$ for roots and starch, respectively, in the treatment where the culture remained with the presence of weeds from planting to harvest.

According to the results for root production (Table 2), accepting a loss of $1 \%$, the 'Fécula Branca' cassava crop may remain in coexistence with weeds for 66 days after planting $(\mathrm{PBI}=66 \mathrm{DAP})$; the total period of interference prevention was 88 days (TPIP $=88$ DAP). The interval between these two periods defines the critical period of interference (CPI), during which the control practices must be effectively carried out. Thus, CPI was approximately 22 days (CPI between 66 and 88 DAP).

Table 2 - Period before interference (PBI), total period of interference prevention (TPIP) and critical period of interference (CPI) of the weed community in the 'Fécula Branca' cassava crop, considering acceptable loss levels 1\% and 5\%. 2011/2012, Paraná, BR

\begin{tabular}{|l|c|c|c|}
\hline \multirow{2}{*}{$\begin{array}{c}\text { Production } \\
\left(\mathrm{t} \mathrm{ha}^{-1}\right)\end{array}$} & PBI & TPIP & CPI \\
\cline { 2 - 4 } & \multicolumn{3}{|c|}{ Days after planting } \\
\hline Roots & 66 & 88 & 66 to 88 \\
\hline Starch & 70 & 91 & 70 to 91 \\
\hline & \multicolumn{3}{|c|}{$5 \%$ loss } \\
\hline Roots & 87 & 80 & - \\
\hline Starch & 88 & 81 & - \\
\hline
\end{tabular}

Considering the starch production for a tolerable loss of $1 \%$, it was found that the PBI was of 70 DAP, TPIP was of 91 DAP and CPI was of 70-91 DAP. These data are very close to the periods found for root production (Table 2).

Assuming acceptable loss levels of 5\% (Table 2) for both root production and for the starch, there was an increase in interference periods (days). For root production, the PBI found was $87 \mathrm{DAP}$, and the period's TPIP was of 80 DAP. Regarding the data for starch production, PBI and TPIP were of 88 and 81 DAP, respectively. Thus, in both parameters, it can be seen that the PBI was greater than the TPIP - in this case, the CPI has not occurred. Thus, according to Pitelli \& Durigan (1984), when this fact occurs, the weed control at a time is enough, as long as it is performed between the end of PBI and the end of TPIP, so that the culture can express its productive potential.

The PBI obtained for roots of 66 DAP differs from the result obtained by Carvalho et al. (2004) (20 DAP), Albuquerque et al. (2008, 2012) (25 DAP) and Biffe et al. (2010) (18 DAP). This fact can be attributed to soil and climate differences, infestation and composition of weeds in the area, cultivar, spacing, among others. However, it is very close to that obtained by Johanns \& Contiero (2006), 60 DAP, in a work also made with the 'Fécula Branca' cassava variety in the same region, Marechal Cândido Rondon - PR (agricultural year 2001/02).

On Table 3, the equations on roots and starch yield curves are described, where it can be seen that the roots show a reduction of $0.573 \%$ in the cassava crop yield for every day coexisting with weeds. Likewise, each day coexisting with weeds reduced the yield of starch by $0.583 \%$.

Thus, considering yield levels of cassava roots production of $10 \mathrm{t} \mathrm{ha}^{-1}$ and assuming the average price of the crop of $R \$ 210.00 \mathrm{t}^{-1}$ and the control cost of $R \$ 300.00 \mathrm{ha}^{-1}$, it is possible to estimate the WEEPPEL of approximately 20 DAP for the situation where weeds reduce the yield by $0.573 \%$ per day of coexistence (Figure 5).

Table 3 - Equations of the first segment of the yield curves of roots of 'Fécula Branca' cassava in function of days of coexistence of the crop with weeds. 2011/2012, Paraná, BR

\begin{tabular}{|l|c|c|c|c|c|}
\hline \multicolumn{1}{|c|}{ Yield } & Equations & Yield Loss (PR)* & $\mathrm{R}^{2}$ & "F" Value & Probability \\
\hline Roots & $\hat{y}=10.598-0.0607 \mathrm{X}$ & 0.00573 & 0.85 & 21.773 & 0.010 \\
\hline Starch & $\hat{y}=1.647-0.0096 \mathrm{X}$ & 0.00583 & 0.75 & 12.042 & 0.026 \\
\hline
\end{tabular}

$* \mathrm{PR}$ is the result of the ratio of parameters $\mathrm{b} / \mathrm{a}$ of the linear regression equations. 


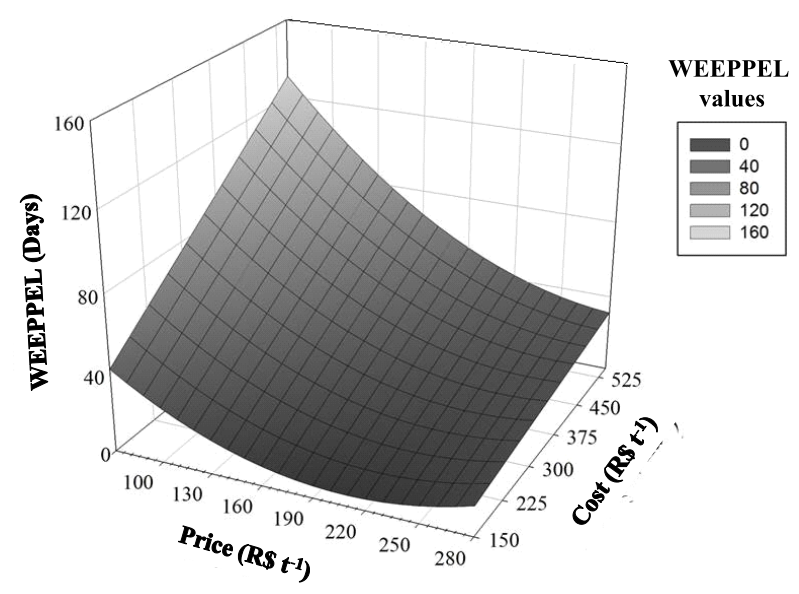

$\mathrm{WEEPPEL}=47.13178263-0.67283722 *$ Price + $0.00192347 *$ Price $^{2}+0.28020233 *$ Cost $+0.0000007 *$ Cost $^{2}$ $0.00086173 *$ Price $*$ Cost.

Figure 5 - Estimated weed period prior to economic loss (WEEPPEL) caused by the coexistence of weeds after planting the crop (cultivation of 322 days $=1$ cycle), whereas weeds reduce $0.573 \%$ of root production per day of coexistence and the crop yield is $10 \mathrm{tha}^{-1}$. 2011/2012, Paraná, BR.

Another interpretation that can be made - in conditions of high crop values, ranging between $R \$ 210$ and $R \$ 280$ per ton, and reduced control cost $\left(\$ 150.00 \mathrm{ha}^{-1}\right)$ - is that it would be economically satisfactory to adopt preemergence control of weeds so that they had no interference in the early stages of the crop cycle. This means that the reduced value of WEEPPEL (6 to 15 DAP) and factors that stop the control in early post-emergence (rain, for example) would financially compromise the crop yield (Vidal et al., 2005). In this case, weed control may be performed even before the period found for PBI (66 and 87 DAP for acceptable loss of $1 \%$ and $5 \%$, respectively).

However, under high control cost $\left(\mathrm{R} \$ 550.00 \mathrm{ha}^{-1}\right)$ and low price $\left(\mathrm{R} \$ 70.00 \mathrm{t}^{-1}\right)$ conditions, we noticed a much higher WEEPPEL of 131 DAP; in which case the weed control would not need to be done, because the crop would have closed the spacing, which could suppress the development of these plants due to the shadowing effect.

For control cost values of $\mathrm{R} \$ 550.00 \mathrm{ha}^{-1}$, which corresponds to the cost for the period of two crop cycles, and price of $\mathrm{R} \$ 280,00 \mathrm{t}^{-1}$ (highest price paid in the far west of Paraná in the 2011/12 period, according to CEPEA, 2012) we noted a WEEPPEL value of 31 DAP. According to Vidal et al. (2005), the higher the level of technology adopted by the producer, the greater the economic return of the investment dedicated to early control of weeds, and the earlier should be the control the is the cost of the control adopted. However, the higher the crop yield potential and the better the conditions for its development, the lower the daily losses caused by certain weed species will probably be.

Comparing the values obtained for WEEPPEL and for PBI for the cassava crop (Figure 3), in practice, it is understood that if the producer was to adopt the PBI with acceptable losses in the production of roots of $1 \%$ and $5 \%$, losses would occur of 2.9 and 4.6 tons or $R \$ 634.81$ and $R \$ 1,006.94 \mathrm{ha}^{-1}$, respectively. However, if the producer was to adopt the WEEPPEL of 20 DAP, considering the price of the crop estimated at $R \$ 218.90 \mathrm{t}^{-1}$ and the cost of control of R\$300.00 ha h $^{-1}$ (average values paid at the far west of Parana in the period up to March 2012 (CEPEA, 2012)), he would have lost $200 \mathrm{~kg}$ or $\mathrm{R} \$ 43.78 \mathrm{ha}^{-1}$.

Thus, it can be seen that the financial losses when considering the PBI values of 66 and 87 DAP (Table 2) were higher than the average control cost practiced in the first cycle of the culture, in the region where the study was conducted. Therefore, it can be stated that the economic aspects, such as cost of weed control and crop price, should be used as indicators of periods of weed interference (Vidal et al., 2005).

In Figure 6 are estimates of WEEPPEL caused by coexistence of weeds after emergence of the crop (cultivation of 322 days $=1$ cycle), whereas weeds reduce $0.583 \%$ of the production of starch per day of coexistence, with a yield of $1.5 \mathrm{t} \mathrm{ha}^{-1}$.

Thus, considering the average starch value of $R \$ 1,200.00 \mathrm{t}^{-1}$ and the control cost of $\mathrm{R} \$ 300.00 \mathrm{ha}^{-1}$, one can predict a WEEPPEL of approximately 24 DAP. As for cost control values of $R \$ 550.00 \mathrm{ha}^{-1}$, which corresponds to the cost for the period of two crop cycles, and the starch price of $R \$ 1,600.00 \mathrm{t}^{-1}$ (highest price paid in the far west of Paraná in the 2011/12 


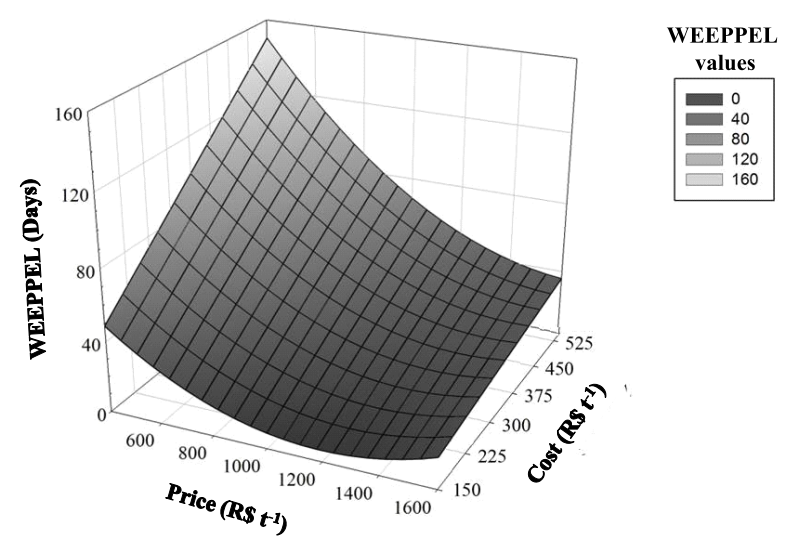

$\mathrm{WEEPPEL}=54.00300063-0.13509938^{*}$ Price $+0.00006754 *$ Price $^{2}+0.32196135 *$ Cost $-0.00000037 *$ Cost $^{2} \quad$ $0.00017275 *$ Price* Cost.

Figure 6 - Estimated weed period prior to economic loss (WEEPPEL) caused by the coexistence of weeds after planting the crop (cultivation of 322 days $=1$ cycle), whereas weeds reduce $0.583 \%$ of starch production per day of coexistence and the crop yield is $1.5 \mathrm{t} \mathrm{ha}^{-1}$. 2011/2012, Paraná, BR.

period, according CEPEA, 2012), a WEEPPEL value of 36 DAP was observed.

It is noteworthy that these values are slightly higher than the WEEPPEL values obtained for the roots data, which may indicate that, depending on the parameter analyzed for the WEEPPEL estimate, there may be variations and practical consequences in deciding the ideal period for weed control. The same behavior was also observed for the estimates of PBI, TPIP and CPI.

Therefore, if in practice the producer was to adopt the PBI with acceptable losses in starch production of $1 \%$ and $5 \%$ to determine the period of weed control, there would be losses of $430 \mathrm{~kg}$ and $690 \mathrm{~kg}$, or R\$ 512.49 and $\mathrm{R} \$ 822,37 \mathrm{ha}^{-1}$, respectively (Figure 4). However, if the producer was to adopt the WEEPPEL of 24 DAP, based on the starch price of $R \$ 1,191.84 \mathrm{t}^{-1}$, and control cost of $R \$ 300.00$ ha $^{-1}$ (average values paid in the far west of the Paraná in the period up to March 2012, according to CEPEA, 2012), he would have lost $30 \mathrm{~kg}$ or $\mathrm{R} \$ 35.76 \mathrm{ha}^{-1}$.

Data comparison between PBI and WEEPPEL, both for root and starch production, were similar to those obtained by Parreira et al. (2012), working with the bean crop.
According to Vidal et al. (2005), similarly to WEEPPEL, it would be possible to determine the total period of prevention of economic loss (TPPEL) as well as the critical period of prevention of economic loss (CPPEL). However, the formula proposed for WEPPEL seems inappropriate to make TPPEL estimates, since the results of simulations made with data from control periods showed no practical logic.

Hence, there is need for formulation of mathematical models that allow to obtain results that express the same meaning of PTIP and the use of monetary data to economically justify the adoption of weed control measures in the period or phase of the culture more sensitive to interference.

Based on these results, we can conclude that the coexistence of the 'Fécula Branca' cassava crop throughout the cycle with the weeds caused significant differences when compared to maintaining the culture clean. It was found that, depending on the parameter analyzed (root or starch production), PBI, TPIP, CPI and WEPPEL estimates showed variations in determining the control period, which may influence the decision making regarding strategies of weed management in cassava. So, when comparing WEEPPEL estimates of 20 and 24 DAP (considering average economic values) for roots and starch production, respectively, with the CPI estimates between 66-88 and 70-91 DAP (considering acceptable losses of $1 \%$ ) for root and starch production, respectively, it was observed that the weed management should be performed earlier when economic data are used in the weed control period estimates. Therefore, this practice can ensure higher profit return to the producer than when using CPI estimates, which are usually determined with arbitrary values of crop yield losses.

\section{LITERATURE CITED}

ALBUQUERQUE, J. A. A. et al. Interferência de plantas daninhas sobre a produtividade da mandioca (Manihot esculenta). Planta Daninha, v. 26, n. 2, p. 279-289, 2008

ALBUQUERQUE, J. A. A. et al. Desenvolvimento da cultura de mandioca sob interferência de plantas daninhas.

Planta Daninha, v. 30, n. 1, p. 37-45, 2012 
CARVALHO, J. E. B.; ARAÚJO, A. M. A.; AZEVEDO, C. L. L. Período de controle de plantas infestantes na cultura da mandioca no Estado da Bahia. Cruz das Almas: Embrapa CNPMF, 2004. 7 p. (Comunicado Técnico, 109).

CENTRO DE ESTUDOS AVANÇADOS EM ECONOMIA APLICADA - CEPEA. Mandioca. Disponível em: $<$ http:// www.cepea.esalq. usp.br/mandioca/\#>. Acesso em: 4 abr. 2012.

EMPRESA BRASILEIRA DE PESQUISA AGROPECUÁRIA - EMBRAPA. Centro Nacional de Pesquisa de Solos. Sistema brasileiro de classificação de solos. 2.ed. Brasília: Embrapa Produção de Informação; Rio de Janeiro: Embrapa Solos, 2006. 306 p.

\section{INSTITUTO BRASILEIRO DE GEOGRAFIA E}

ESTATÍSTICA - IBGE. Levantamento Sistemático da produção Agrícola: pesquisa mensal de previsão e acompanhamento das safras agrícolas no ano civil: maio, 2011

Levant. Sistem. Prod. Agríc., v. 24, n. 5, p. 1-82, 2011.

\section{INSTITUTO PARANAENSE DE DESENVOLVIMENTO} ECONÔMICO E SOCIAL - IPARDES. Base de Dados do Estado BDEweb. Estado do Paraná, Produção Agrícola, Mandioca, Rendimento médio, 2009. Disponível em: $<\mathrm{http}: / /$ www.ipardes.gov.br/imp/index.php>. Acesso em: 25 jul. 2011.

JOHANNS, O.; CONTIERO, R. L. Efeitos de diferentes períodos de controle e convivência de plantas daninhas com a cultura da mandioca. R. Ci. Agron., v. 37, n. 3, p. 326-331, 2006.

KISSMANN, K. G.; GROTH, D. Plantas infestantes e nocivas. São Paulo: Basf Brasileira, 1992. v. 2. 798 p.

KOZLOWSKI, L. A. et al. Período crítico de interferência das plantas daninhas na cultura do feijoeiro-comum em sistema de semeadura direta. Planta Daninha, v. 20, n. 2, p. 213-220, 2002.
MUELLER-DOMBOIS, D.; ELLENBERG, H. Aims and methods of vegetation ecology. New York: John Wiley \& Sons, 1974. 547 p

OLIVEIRA, N. T. et al. Caracterização e identificação de clones de mandioca produzidos em Roraima para consumo in natura. Agroambiente, v. 5, n. 3, p. 188-193, 2011.

PARANÁ. Secretaria Estadual da Agricultura e do Abastecimento - SEAB. Estimativa de safra 2011/2012. Disponível em: $<$ http://www.seab.pr.gov.br/arquivos/File/deral/ pss.xls $>$. Acesso em: 21 mar. 2012

PARREIRA, M. C. et al. Modeling of weeds interference periods in bean. Planta Daninha, v. 30, n. 4, p. 713-720, 2012.

PERESSIN, V. A. et al. Acúmulo de matéria seca na presença e na ausência de plantas infestantes no cultivo de mandioca SRT 59-branca de Santa Catarina. Bragantia, v. 57, n. 1, p. 1-16, 1998.

PITELLI, R. A.; DURIGAN, J. C. Terminologia para períodos de controle e de convivência das plantas daninhas em culturas anuais e bianuais. In: CONGRESSO BRASILEIRO DE HERBICIDAS E PLANTAS DANINHAS, 15., 1984, Belo Horizonte. Resumos... Belo Horizonte: SBHDE, 1984 p. 37.

VIDAL, R. A.; FLECK, N. G; MEROTTO Jr., A. Período anterior ao dano no rendimento econômico (PADRE): nova abordagem sobre os períodos de interferência entre plantas daninhas e cultivadas. Planta Daninha, v. 23, n. 3, p. 387-396, 2005.

ZOSCHKE, A.; QUADRANTI, M. Integrated weed management: Quo vadis? Weed Biol. Manag., v. 2, n. 1, p. 1-10, 2002. 